\title{
Development of OrSAEv Model Learning: Preliminary Study of Students' Prepareness Facing Volcanic Eruption Disaster
}

\author{
*S Nurvitasari ${ }^{1}$, Madlazim $^{2}$, Wasis $^{2}$ \\ 1Postgraduate Program of Science Education Study Program Universitas Negeri Surabaya, Surabaya 60213, Indonesia \\ ${ }^{2}$ Department of Physics, Faculty of Mathematics and Natural Science, Universitas Negeri Surabaya, Surabaya 60231, \\ Indonesia
}

\begin{tabular}{l} 
Article Info \\
\hline Article history: \\
Received March 2, 2021 \\
Revised April 29, 2021 \\
Accepted April 30, 2021 \\
Available Online April 30, 2021 \\
\hline
\end{tabular}

\section{Keywords:}

Disaster Preparedness OrSAEv Learning Model Volcano Eruption

\begin{abstract}
Geologically, Indonesia is a country prone to disasters, particularly volcanic eruptions. One of the steps that can be taken to minimize the impact of volcanic eruptions is through the education sector as foundation the knowledge, attitudes, and skills of students. Therefore, this study aims to determine the preparedness of students in dealing with volcanic eruptions based on aspects of knowledge about volcanic eruptions, responsiveness in dealing with volcanic eruptions, and evacuation skills in dealing with volcanic eruptions. The subjects of the study were 26 students from 8th grade at Junior High School of 1 Ngancar. Research method in this study is by interviews and tests. Samples of respondents were taken randomly based on suggestions from science teachers at Junior High School of 1 Ngancar. The results of the research that have been carried out are as follows: Student preparedness is still in the poor category, seen from the aspect of knowledge and skills in evacuation, while the aspect of disaster response attitudes shows conflicting results, where based on the test of disaster response attitudes, $83.3 \%$ is in the good category. However, based on interviews with science teachers, it shows that the facilities, and there has never been any socialization related to disaster mitigation in the school environment. Therefore, it is necessary to do an application test to find out whether disaster response attitudes are truly embedded in students.
\end{abstract}

\section{INTRODUCTION}

Disasters are a series of events that threaten and disrupt human life and livelihoods caused by natural and/or non-natural factors, resulting in casualties, environmental damage, losses, and psychological impacts (Undang-undang Nomor 24 Tahun 2007). Natural disasters include earthquakes, tsunamis, volcanic eruptions, floods, drought, typhoons, and landslides (BNPB, 2015). To minimize risks or losses for humans due to disasters, knowledge, understanding, and disaster preparedness skills are needed by detecting and anticipating early various kinds of disasters (ISDR, 2019).

Geologically, Indonesia is one of the equatorial countries located at the junction of three main plates, namely the Eurasian plate in the north, the Indo-Australian plate in the south, and the Pacific plate in the east or known as the Pacific ring of fire (ring of fire zone). In this area it forms about 40,000 horseshoes (25,000 miles) from South America to North America via the Bering Strait, Japan to New Zealand (Hariyono, 2016). Throughout the ring of the fire zone, it is noted that there are more than 130 active volcanoes in Indonesia, it is proven that Indonesia is a country that has the most active volcanoes in the world (Hariyono et al, 2016). The distribution 
of volcanoes is mostly found on the island of Java (Innatesari, 2015). One of the active volcanoes on the island of Java is Kelud Mt. Mount Kelud is a volcano located in East Java Province, bordering Kediri, Blitar, and Malang Regencies with coordinates $7^{\circ} 56^{\prime} 00^{2}$ South Latitude and $112^{\circ} 18^{\prime} 30^{2}$ East Longitude and has an altitude of 1731 masl (Syiko et al, 2014). Many of the historic eruptions of Mount Kelud, except the passive lava dome eruption in 2007, are characterized by short duration, high explosions, and large tephra volumes. Since 1000 AD, Mount Kelud has experienced about 40 eruptions (Siebert et al, 2014; Andriastuti et al, 2019). The last eruption occurred on February 13, 2014, with a total volume of volcanic material of 219 million m3, which is predominantly spread west-southwest of Mount Kelud. Throw stones are also scattered towards the north-southwest (Kediri city) and the ashes are scattered to West Java (Heriwaseso, 2017). Based on data from the Mount Kelud Disaster Management Agency, the number of fatalities due to the eruption of Mount Kelud in 2014 as many as 7 people died, 31 people were hospitalized, 1,892 people were outpatients and 8,622 housing damage were severely damaged with a total loss of 392. 6 AD (Sugara, 2018).

A large number of casualties and losses incurred during a disaster shows that the Local communities lack of preparedness in facing disasters and lack of knowledge to deal with disasters (Syah, 2019). Lack of disaster preparedness can increase community risk to disaster threat (Santoso \& Juhadi, 2017). Schools play an important role in building disaster awareness in the community, thus the efforts made are how to make leaening activity that are ready to face natural disasters (Adiyoso \& Kanegae, 2013). The 2013 curriculum was developed by the Government based on awareness so that students in Indonesia can recognize potential disasters. This is evident in the natural science subjects for Junior High School or Islamic Junior High School level in Permendikbud Number 24 of 2017 in Basic Competency 3.10 Explaining the layers of the earth, volcanoes, earthquakes, and risk reduction measures before, during, and after a disaster according to the threat of a disaster area (Rahayu et al, 2019). This shows how important disaster mitigation education is in Indonesia. Disaster mitigation education taught in schools will shape the character of students who are ready to face every disaster that occurs (Isna et al, 2019). The ability of students to understand the potential disasters that exist around their house (local area) is very important (Pahlevaan, 2019). The knowledge they have can usually influence attitudes and awareness to be prepared in anticipation of disasters (Firmansyah et al, 2014). Preparedness will be formed if students have provisions in terms of disaster mitigation knowledge and skills that can be embedded in the school environment in learning activities (Elfiana et al, 2019). According to Madlazim (2020) Disaster preparedness has three main aspects: disaster knowledge, disaster response attitude, and post-disaster evacuation skills (Madlazim et al, 2020).

However, in reality, it is very rare for disaster material to be provided properly, according to plans and learning practices that are interesting, fun, and useful for students. Most learning activities rely more on text from practical student books and worksheets to provide summary material along with practice questions. Not many have taken the initiative to develop real contextual learning. According to (Apriyani, 2019) in her research at an elementary school in Yogyakarta, August 2014, disaster preparedness education has a good effect, students show a responsive attitude, but for school themselves they are still not ready because so far learning about disasters still uses conventional learning models. Therefore, innovative learning models are needed specifically to strengthen disaster preparedness, especially volcanic eruption disasters for students. A suitable learning model to strengthen student preparedness in facing disasters is the OrSAEv Learning Model (Orientation, Preparedness, Action, and Evaluation Orientation) (Madlazim et al, 2020). The OrSAEv model is considered suitable for improving disaster preparedness because in its learning activities it not only provides knowledge about disasters but is accompanied by direct action in dealing with disasters. An educator must provide initial training guidance, and must convey information step by step (Katsur et al, 2020). This can be found at the stages of the OrSAEv learning model, where educators show action 
steps before a disaster, during a disaster, and during a disaster. The steps for learning activities from the OrSAEv model are the first activity, Orientation (Or) aims to attract students 'interest, focus students' attention, and motivate students to take an active role in the learning process. The second activity, Disaster Preparedness, is conceptual-based learning that is carried out to provide basic knowledge about disasters. The third activity, Action (A) is practical learning carried out with the intention that students can have skills in disaster. The fourth activity, Evaluation (Ev) aims to evaluate students' disaster knowledge, as well as prepare follow-ups (Madlazim, 2019). The instructional impact of the OrSAEv learning model is to improve disaster preparedness, especially knowledge about disasters, disaster response attitudes, and disaster evacuation skills.

Based on the explanation above, teaching materials are needed that support disaster learning so that students' preparedness in facing disasters can increase. To determine the level of student preparedness, before developing the device, an analysis of the level of student preparedness in facing disasters was carried out first. Therefore, this study is to conduct "Development of OrSAEv Model Learning: Preliminary Study of student preparedness in the face of volcanic eruption disaster".

\section{RESEARCH METHOD}

\section{Types of Research}

The type of research used is descriptive quantitative research to see the extent to which students are prepared to face disasters.

\section{Research subject}

The subjects of this study were 26 students of 8th grade at Junior High School of 1 Ngancar. Samples of respondents were taken randomly based on suggestions from science teachers at Junior High School of 1 Ngancar.

\section{Research Instrument}

The instrument used was adopted from (Kristanti, 2013) in research conducted in the Yogyakarta area. The research instruments used include: (1) a test sheet for knowledge and preparedness in dealing with volcanic eruption disasters. (2) Attitude test sheet in dealing with volcanic eruptions. (3) Skill sheet for evacuation in the face of volcanic eruptions. (4) Interview sheets for teachers.

\section{Data Analysis Technique}

The data analysis technique was carried out by univariate analysis. Univariate analysis was performed on the variables used in the study. The purpose of this analysis is to see an overview of the frequency distribution of each variable under study. The percentage scale to determine the readiness of students uses the following formula:

$$
\text { Average value } \%=\frac{\sum \text { the student } \text { who answered correctly }}{\sum \text { student }}
$$

The results of data analysis are presented in the form of a frequency distribution table. Interpretation of the level of preparedness (knowledge of disasters, disaster response attitudes, and evacuation skills) of students in dealing with volcanic eruptions according to Jan Sopaheluwakan in (Syaifullah, 2014), is divided into 5 categories, namely:

Table 1. Disaster Preparedness Level Index 
Development of OrSAEv Model Learning: Preliminary Study of Students' Prepareness Facing Volcanic Eruption Disaster

\begin{tabular}{cc}
\hline Index Value & Category \\
\hline $80 \%-100 \%$ & Very Ready \\
$65 \%-79 \%$ & Ready \\
$55 \%-64 \%$ & Almost Ready \\
$40 \%-54 \%$ & Not ready \\
$>40 \%$ & Not ready \\
\hline
\end{tabular}

This research was conducted with two different activities continuously, the first is a preliminary study to determine the level of preparedness of students in the face of volcanic eruptions at Junior High School of 1 Ngancar. The next research stage is to develop disaster learning tools based on the 4D development method by Thiagarajan, Dorothy S. Semmel, and Melvyn I. Semmel (1974). Development research is carried out in four stages, namely: define, design, develop, disseminate (Thiagarajan, 1974; Ahmad \& Asmaidah, 2017).

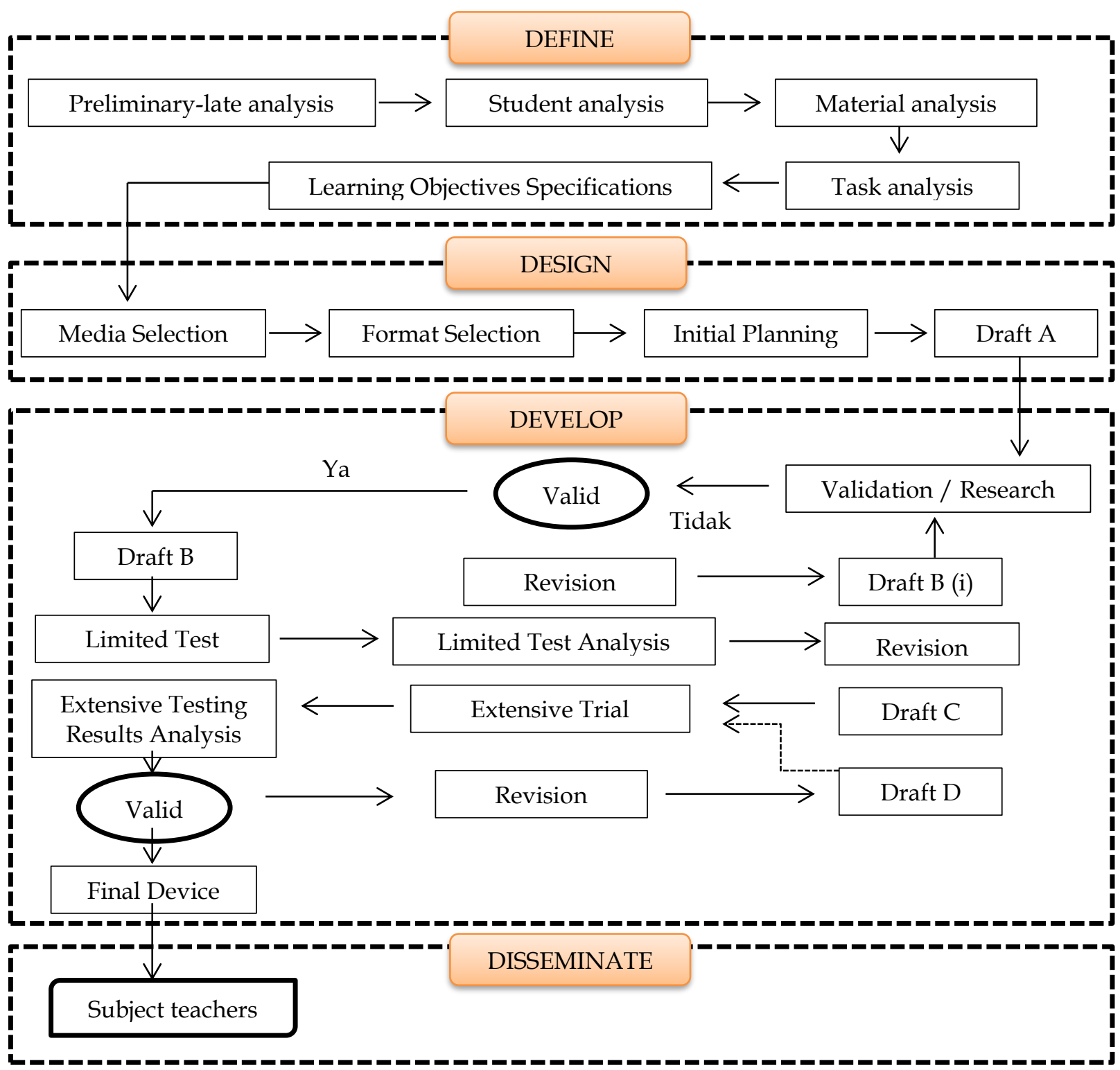

Figure 1. Research procedure

\section{RESULTS AND DISCUSSION}

This study aimed to find an overview of students' preparedness in facing volcanic eruption disasters. This research was conducted using test and interview. The disaster preparedness test sheet consists of 2 questions to determine disaster response attitudes, 11 questions to find out 
disaster knowledge, and 1 question about evacuation skills to determine students' actions in dealing with volcanic eruptions. Interview sheets to find out the history of disasters that occurred in Ngancar District and lessons related to volcano material in schools.

\section{Results of interviews with teachers}

Interviews were conducted with two teachers at Junior High School of 1 Ngancar. The first teacher interviewed was a science teacher who had been teaching for 14 years. The teacher explained that Junior High School of 1 Ngancar was an area prone to eruptions from Mount Kelud. "At the time of the 2014 eruption, all residents around the school were asked to evacuate one hour before the mountain finally erupted". According to the science teacher, in delivering volcano material, it is usually taught using powerpoint media "for rescue simulation when a disaster has never been done". Disaster specific learning materials do not yet exist and there are no evacuation routes at schools.

The second teacher who was interviewed was the deputy head of the curriculum at Junior High School of 1 Ngancar, it was known that there had never been any socialization related to disaster mitigation in the school environment so there was no awareness to be aware of possible disasters that could occur at any time. "There is no encouragement from the government and school principals to specifically teach disaster".

From interviews conducted with two teachers at Junior High School of 1 Ngancar, it was found that there had never been any disaster mitigation socialization, so there was no awareness to be aware of possible disasters. The absence of encouragement from the government and school principals led to disaster-based learning being carried out only by reading and taking test questions without direct action from disaster simulations. School facilities do not specifically support disaster learning, other than that there are no evacuation routes at schools.

\section{The level of preparedness of students to face volcanic eruptions}

Based on data obtained from the disaster preparedness test given to 25 students of Junior High School of 1 Ngancar. The student's preparedness test involves three aspects, namely knowledge of disasters, disaster response attitudes, and skills to evacuate volcanic eruptions. Student preparedness is calculated based on the respondent's answer, if the answer is wrong it gets a value of 1 and if the answer is correct it gets a score of 2 .

\section{The results of the preparedness test from the aspect of students' knowledge about volcanic} eruptions

This test contains 10 questions which include 5 questions with multiple choice answers and 5 essay questions. The percentage of students' answers in answering the volcanic eruption disaster knowledge test is presented in the Table 2.

Table 2. Distribution of respondents' answers based on a test of knowledge about volcanic eruptions at Junior High School of 1 Ngancar

\begin{tabular}{|c|c|c|c|}
\hline \multirow[b]{2}{*}{ No. } & \multirow[b]{2}{*}{ Disaster Knowledge Question } & \multicolumn{2}{|c|}{ Student Answers } \\
\hline & & $\begin{array}{c}\text { Correct } \\
(n=26) \\
0\end{array}$ & $\begin{array}{c}\text { False } \\
(\mathrm{n}=26) \\
\quad \%\end{array}$ \\
\hline 1. & $\begin{array}{l}\text { A series of events, whether caused by humans, nature, or a } \\
\text { combination of the two that can cause casualties, property } \\
\text { loss and environmental damage are called ... }\end{array}$ & 73 & 27 \\
\hline 2. & $\begin{array}{l}\text { Below are the activities in disaster management cycle in the } \\
\text { pre / pre-disaster stage are ... }\end{array}$ & 57,7 & 42,3 \\
\hline 3. & $\begin{array}{l}\text { Knowing the actions that are fast and appropriate in dealing } \\
\text { with disasters to minimize losses due to disasters, is an } \\
\text { activity ... }\end{array}$ & 61,5 & 38,5 \\
\hline
\end{tabular}




\begin{tabular}{|c|c|c|c|}
\hline \multirow[b]{2}{*}{ No. } & \multirow[b]{2}{*}{ Disaster Knowledge Question } & \multicolumn{2}{|c|}{ Student Answers } \\
\hline & & $\begin{array}{c}\text { Correct } \\
(\mathrm{n}=26) \\
0\end{array}$ & $\begin{array}{c}\text { False } \\
(\mathrm{n}=26) \\
\%\end{array}$ \\
\hline 4. & $\begin{array}{l}\text { A series of efforts to reduce disaster risk, for example } \\
\text { creating a disaster warning system, are steps ... }\end{array}$ & 69,2 & 30,8 \\
\hline 5. & $\begin{array}{l}\text { What are you doing when the warning of the mountain to } \\
\text { erupt has been sounded while you are in the class? }\end{array}$ & 53,9 & 46,1 \\
\hline 6. & What caused the mountain to erupt? & 42,3 & 57,7 \\
\hline 7. & $\begin{array}{l}\text { In your experience, what are the signs that a mountain will } \\
\text { erupt? }\end{array}$ & 46,2 & 53,8 \\
\hline 8. & $\begin{array}{l}\text { Mention and explain the warning stages given by BMKG } \\
\text { when a mountain is about to erupt! }\end{array}$ & 38,4 & 61,6 \\
\hline 9. & $\begin{array}{l}\text { Mention the dangerous impact of the eruption of Mount } \\
\text { Kelud? }\end{array}$ & 73 & 27 \\
\hline 10. & $\begin{array}{l}\text { What steps should you take before, during, and after a } \\
\text { volcanic disaster erupts? }\end{array}$ & 27 & 73 \\
\hline & Average & 54,2 & 45,8 \\
\hline
\end{tabular}

Preparedness from the aspect of students' knowledge about volcanic eruptions after adding the percentage of each question then divided by the number of questions the result was $54.2 \%$ or according to Arikunto, the student's knowledge was classified as category 4 which was started in the not ready category (Syaifullah, 2014). There are several reasons why this could happen, firstly because there is no appropriate teaching material to teach disaster preparedness education. Second, school facilities that do not support, such as the absence of disaster mitigation books, disaster posters, and evacuation routes to support disaster preparedness education. In its implementation, preparedness education cannot be carried out only one side, collaboration and commitment of high school members and support from the government and the community, in general, must work collaboratively for the success of instilling preparedness education (Susanti et al, 2014).

\section{The results of the preparedness test from the aspect of student responsiveness about volcanic eruptions}

This test contains 2 questions with essay answers. The percentage of students' answers in answering the volcano eruption disaster response attitude test is presented in Table 3.

Table 3. Distribution of respondents' answers based on the volcanic eruption response attitude test at Junior High School of 1 Ngancar

\begin{tabular}{|c|c|c|c|}
\hline \multirow[b]{2}{*}{$\begin{array}{l}\text { Attitude } \\
\text { Indicator }\end{array}$} & \multirow[b]{2}{*}{ Disaster Response Attitude Questions } & \multicolumn{2}{|c|}{ Student Answers } \\
\hline & & $\begin{array}{c}\text { Correct } \\
(\mathrm{n}=26) \\
\%\end{array}$ & $\begin{array}{c}\text { False } \\
(\mathbf{n}=26) \\
\quad \%\end{array}$ \\
\hline Care & $\begin{array}{l}\text { After the Mount Meets is declared safe by Meteorology } \\
\text { Climatology and Geophysics Council, around your } \\
\text { residence some items can still be used but these items are } \\
\text { not only yours but mixed with other people's belongings. } \\
\text { What should you do with these items? }\end{array}$ & 80,7 & 19,3 \\
\hline Alert & $\begin{array}{l}\text { As a student, what needs to be done in the face of an } \\
\text { erupting mountain disaster that can come at any time? }\end{array}$ & 69,2 & 30,8 \\
\hline Religion & $\begin{array}{l}\text { Based on your religious beliefs, what is your attitude as a } \\
\text { student in dealing with the volcanic eruption that can } \\
\text { come at any time? }\end{array}$ & 100 & 0 \\
\hline & Average & 83,3 & 16,7 \\
\hline
\end{tabular}


Student preparedness from the aspect of disaster response attitudes using 3 indicators of volcano eruption disaster response which include care, alertness, and religion. Based on the data above, the average percentage of students' disaster response attitude is $83.3 \%$ in the good category according to Jan Sopaheluwakan. On the alert indicator, 18 students can answer correctly with a percentage of $69.2 \%$, namely determining the closest evacuation route from the school to the evacuation location. This result is theoretical, because attitudes are derived from direct learning outcomes or observing other people. Direct learning outcomes can be through classroom learning activities, while observations are obtained through daily experiences (Djemari, 2016). So, the theoretical results above need to be tested to find out whether the disaster response attitude is planted in students.

The results of the preparedness test from the aspect of students' evacuation skills regarding volcanic eruptions

The preparedness test from the aspect of student evacuation skills is assessed through simple posters made by students. The poster in question contains steps before, during and after a volcanic eruption. Of the 26 students, only 2 students can make a poster containing some steps to prepare for volcanic eruptions. The following are the results of posters from 2 students whose steps are close to the correct.

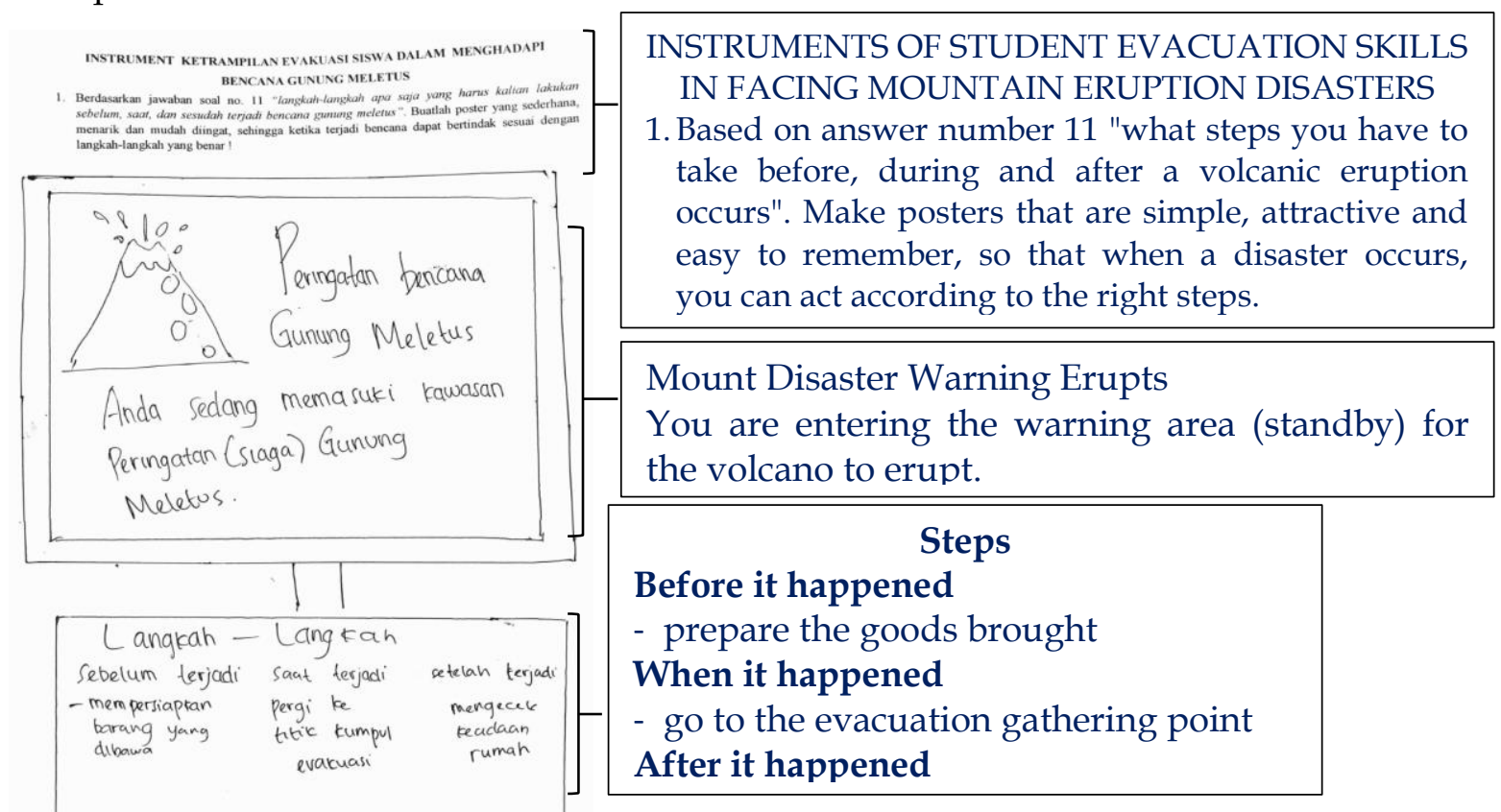

Figure 2. Results of student posters 1 


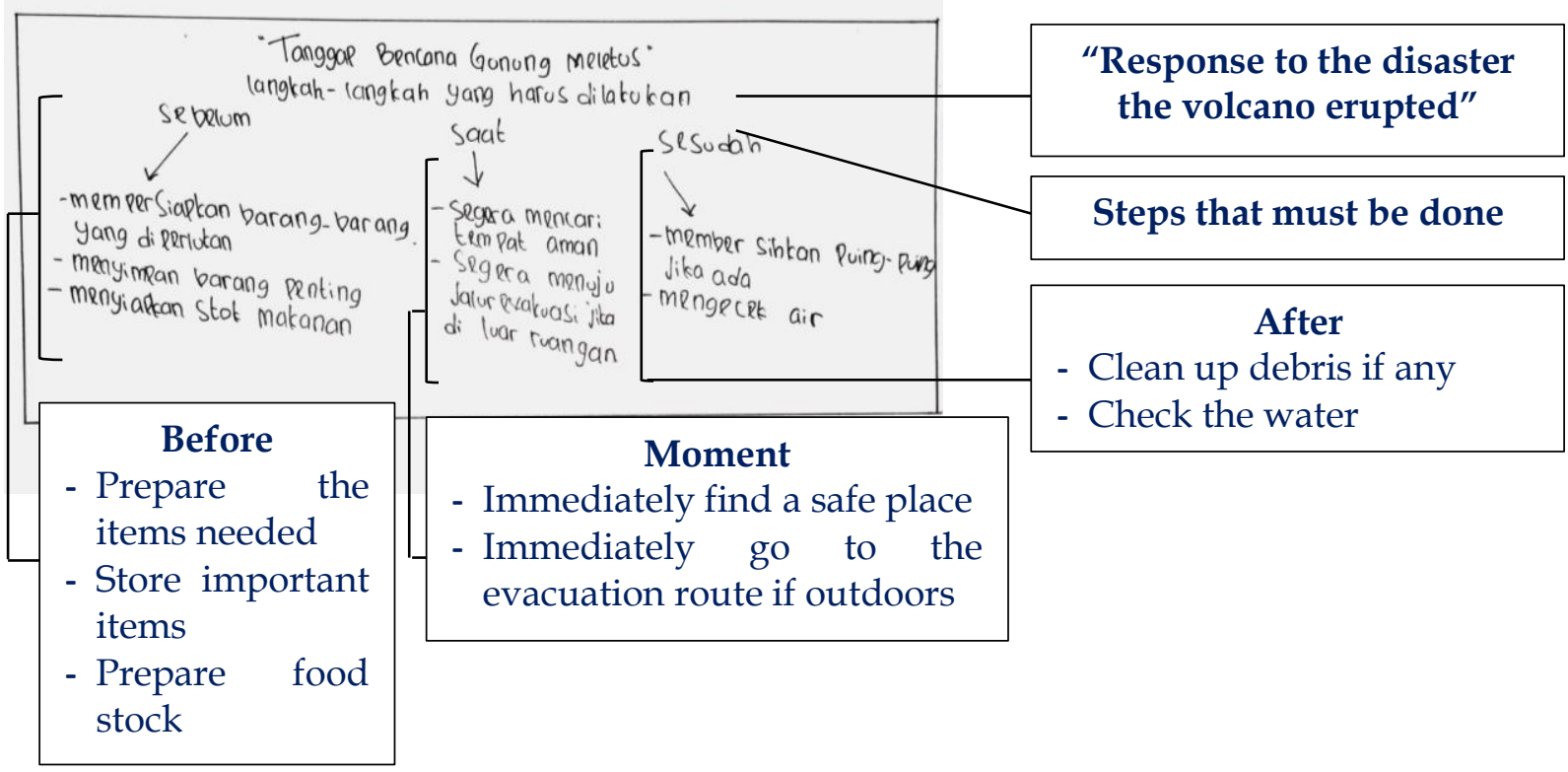

Figure 3. Results of student posters 2

The results of the posters for the two students showed several steps that were by the disaster pocket book issued by National Board for Disaster Management. Based on the disaster pocket book issued by National Board for Disaster Management, the steps that must be taken before the disaster are to pay attention to the direction of the Center for Volcanology and Geological Disaster Mitigation and the development of volcanic activity, to know the evacuation routes and shelters that have been prepared by the authorities, to prepare other evacuation scenarios if the impact of the eruption extends beyond expert predictions, and set up logistical support. Steps that must be taken when a volcanic eruption disaster occurs, namely not being in the recommended location to be vacated, avoiding open spaces, protecting yourself from the ash of volcanic eruptions, using a mask or wet cloth to cover the mouth and nose, and wearing closed protective clothing. body. The steps that must be taken after a volcanic eruption are to avoid driving a car in areas affected by volcanic ash rain because it can damage vehicle engines, clean the roof from volcanic dust piles because its weight can knock down and damage the roofs of houses or buildings, and be aware of river flow areas that are potentially affected by lahar hazards in the rainy season (Yanarto et al, 2019).

Preparedness is strongly influenced by student's cognitive development, where children develop their thought processes so that initiatives arise in carrying out the skills taught and their psychological development so that children can anticipate, identify and be able to control themselves over actions that should be taken to be alert in times of disasters and improve. concern for others in the face of disasters (Bruner \& Lewis 2006; Trianto, 2010). Someone is said to be ready to face a disaster if they have the knowledge to anticipate, respond to, and recover effectively from the impact of an event or hazard that may exist (ADRRN, 2019). Seeing the reality of the importance of students' knowledge, attitudes, and skills in disaster preparedness, researchers are increasingly convinced that disaster preparedness education must be implemented. This is because SMPN 1 Ngancar is at a radius of about $11 \mathrm{~km}$ from Mount Kelud. The choice of learning model also greatly affects the condition of students 'backgrounds and students' interest in learning (Mayani, 2010). Learning methods and learning resources also need to be developed to realize innovative learning. Also, disaster education in schools must be supported by appropriate learning materials (Indriasari, 2016). With appropriate learning materials and learning methods, it can increase students' enthusiasm. Disaster preparedness increases with increased knowledge about disasters, appropriate attitudes towards disasters, 
and more appropriate actions in dealing with disasters (Hayadityas, 2020). Alignment of teacher interview answers and student preparedness test results in facing disasters shows that it is necessary to learn about disasters accompanied by an appropriate learning model and accompanied by direct action simulations in dealing with disasters, therefore the development of learning tools needs to be developed.

\section{CONCLUSION}

Based on the results, analysis, and discussion, it indicates that students' preparedness in dealing with disasters was still lacking in terms of disaster knowledge and skills in disaster evacuation. From the aspect of attitude, it shows the results are in a good category, but this is not in accordance with the results of interviews conducted with teachers at school. The results of interviews with teachers indicated that facilities, experience in dealing with disasters and learning about disasters in the classroom were still lacking. Therefore, appropriate methods and learning materials are needed to improve students' preparedness in facing volcanic eruptions. A person is said to be ready to face a disaster if he has the knowledge to anticipate, respond to and recover effectively from the impact of a possible hazard event or condition. So it can be concluded that the development of volcanic eruption disaster learning for science teachers and students needs to be developed. Future research can be carried out in other disaster-prone areas and carry out a wider scope. Considering that Indonesia is a disaster-prone area such as schools in the Pacitan area which are basically earthquake-prone areas.

\section{ACKNOWLEDGEMENTS}

The author would like to thank Prof. Dr. Madlazim, M.Sc. and Prof. Dr. Wasis, M.Sc., for their support, suggestions, and inspiration in conducting this research. Thank you to the Principal of Junior High School of 1 Ngancar who has allowed to do research, as well as teachers and students who have many roles in this research.

\section{REFERENCES}

Adiyoso, W., \& Kanegae, H. (2013). Efektifitas Dampak Penerapan Pendidikan Kebencanaan di Sekolah terhadap Kesiapsiagaan Siswa Menghadapi Bencana Tsunami Di Aceh. Indonesia. Indonesia. Majalah. indd Spread, 23.

A Heriwaseso, S. D., A Budianto, I. S., Kristiawan, Y., Natalia, M. C., Khoirul, B., \& Kuncoro, D. (2017). Karakter Erupsi Kelud 2014, Pembelajaran dalam Mitigasi Infrastruktur di Kawasan Rawan Bencana. In Proceeding, Seminar Nasional Kebumian Ke-10 Peran Penelitian Ilmu Kebumian dalam Pembangunan Infrastruktur di Indonesia 13-14 September 2017; Graha Sabha Pramana.

Ahmad, M., \& Asmaidah, S. (2017). Pengembangan perangkat pembelajaran matematika realistik untuk membelajarkan kemampuan pemecahan masalah matematika siswa SMP. Mosharafa: Jurnal Pendidikan Matematika, 6(3), 373-384.

Andreastuti, S., Paripurno, E., Gunawan, H., Budianto, A., Syahbana, D., \& Pallister, J. (2019). Character of community response to volcanic crises at Sinabung and Kelud volcanoes. Journal of Volcanology and Geothermal Research, 382, 298-310.

Apriyanti, W. (2019). Implementasi Program Mitigasi Bencana Melalui Sekolah Siaga Bencana di SD Negeri Baluwarti, Kotagede, Yogyakarta. Spektrum Analisis Kebijakan Pendidikan, 8(2), 123-133.

Asian Disaster Reduction Response Network (ADRRN). (2019). Termonology Pengurangan Resiko Bencana. Malaysia: MERCY.

BNPB. 20015. Pusat Data, Informasi dan Humas Badan Nasional Penanggulangan Bencana

Brunner, J \& Lewis, D. (2006). Planning for Emergencies, Principal leadership, 6(8), 65-66.

Djemari, M. (2016). Penilaian Pendidikan Karakter Yogyakarta Universitas Negeri Yogyakarta 
Elfiana, D. E., \& Hariyono, E. (2019). Development of The OrSAEv Learning Materials: Preliminary Study of Student's Knowledge about Earthquake and Tsunami Mitigation. In Journal of Physics: Conference Series, 1417(1), 012083. IOP Publishing.

Firmansyah, I., \& Rasni, H. (2014). Hubungan Pengetahuan dengan Perilaku Kesiapsiagaan dalam Menghadapi Bencana Banjir dan Longsor pada Remaja Usia 15-18 tahun di SMA AlHasan Kemiri Kecamatan Panti Kabupaten Jember (The Correlation Between Knowledge and behavior preparedness in Facing of Floods And Landslides disaster in adolescents aged 15-18 in SMA Al-Hasan Kemiri Sub district Panti of Jember Regency).

Santoso, A. B., \& Juhadi, J. (2017). Pelaksanaan Program Siaga Bencana Di Sekolah Menengah Pertama Pada Kawasan Rawan Bencana. Edu Geography, 5(3), 86-94.

Hariyono, E., Liliasari, Tjasyono, B., \& Madlazim. (2016). Volcanic eruption crisis and the challenges of geoscience education in Indonesia. In AIP Conference Proceedings, 1708(1), 080004). AIP Publishing LLC.

Hariyono, E. (2016). Pengantar Geosains Fokos Kajian : Gunung Api. Surabaya: Unesa University Press.

Hayudityas, B. (2020). Pentingnya penerapan pendidikan mitigasi bencana di sekolah untuk mengetahui kesiapsiagaan peserta didik. Jurnal Edukasi Nonformal, 1(2), 94-102.

Indriasari, F. N. (2018). Pengaruh pemberian metode simulasi siaga bencana gempa bumi terhadap kesiapsiagaan anak di Yogyakarta. Jurnal Keperawatan Soedirman, 11(3), 199-206

Innatesari, D. K., Setiawan, B., \& Sudibyo, E. (2015). Integrasi kearifan lokal pada tema Gunung Kelud terhadap kemampuan literasi sains siswa. In Seminar Nasional Fisika dan Pembelajarannya (1-6).

ISDR, U. (n.d.). (2019). Global assessment report on disaster risk reduction. United Nations International Strategy for Disaster Reduction (UN ISDR). Geneva, Switzerland ISBN/ISSN, 980852698, 207.

Isna, B. U., Hariyono, E., \& Suprapto, N. (2019). Development of OrSAEv Model Learning Materials to Strengthen the Characters of Tsunami Disaster Mitigation for Middle School Students (Preliminary Study). In Journal of Physics: Conference Series, 1417(1), 012082. IOP Publishing.

Kastur, A., Mustaji, M., \& Riyanto, Y. (2020). The Practicality and Effectiveness of Direct Learning Model by Using Life-Based Learning Approach. Studies in Learning and Teaching, 1(3), 165-174.

Madlazim, R. F. (2019). Model Pembelajaran OrSAEv. Surabaya: Penerbit JDS.

Madlazim, Rahmadiati, F., Masriyah, Indana, S., Sunarti, T., \& Prahani, B. K. (2020). An OrSAEv learning model to improve the disaster preparedness of STEM teacher candidates. World Transactions on Engineering and Technology Education, 18(2), 231-236.

Maryani, E. (2010). Model Pembelajaran Mitigasi Bencana Dalam Ilmu Pengetahuan Sosial Di Sekolah Menengah Pertama. Jurnal Geografi Gea, 10(1), $42-58$.

Pahleviannur, M. R. (2019). Edukasi sadar bencana melalui sosialisasi kebencanaan sebagai upaya peningkatan pengetahuan siswa terhadap mitigasi bencana. Jurnal Pendidikan Ilmu Sosial, 29(1), 49-55.

Rahayu, S., Madlazim, M., Prastowo, T., \& Hariyono, E. (2019). Development of OrSAEv Model Learning Materials to Improve Tsunami Disaster Mitigation Skills (Preliminary Study). In Mathematics, Informatics, Science, and Education International Conference (MISEIC 2019), 191194. Atlantis Press.

Siebert, L., Simkin, T., \& Kimberly, P. (2011). Volcanoes of the World. Univ of California Press.

Sugara, A. S., Kusuma, F. H. D., \& Sutriningsih, A. (2018). Hubungan Pengetahuan Dengan Sikap Kesiapsiagaan Masyarakat Menghadapi Erupsi Gunung Kelud Pada Fase Mitigasi. Nursing News: Jurnal Ilmiah Keperawatan, 3(1), 448-458. 
Susanti, R., Sari, S. A., Milfayetty, S., \& Dirhamsyah, M. (2014). Hubungan Kebijakan, Sarana dan Prasarana dengan Kesiapsiagaan Komunitas Sekolah Siaga Bencana Banda Aceh. Jurnal Ilmu Kebencanaan: Program Pascasarjana Unsyiah, 1(1).

Syah, K. (2019). Kualifikasi Penjarahan Pasca Gempa Tsunami dan Likuifaksi di Kota Palu (Suatu Tinjauan Kriminologis). Maleo Law Journal, 3(1), 83-92.

Syaifullah, R. A. (2015). Tingkat Kesiapsiagaan Siswa Kelas XI Dalam Menghadapi Bencana Gempa Bumi Di SMA Muhammadiyah 1 Klaten (Doctoral dissertation, Universitas Muhammadiyah Surakarta).

Syiko, S. F., Rachmawati, T. A., \& Rachmansyah, A. (2014). Analisis Resiko Bencana Sebelum dan Setelah Letusan Gunung Kelud Tahun 2014 (Studi kasus di Kecamatan Ngantang, Malang). Indonesian Journal of Environment and Sustainable Development, 5(2).

Thiagarajan, S. (1974). Instructional development for training teachers of exceptional children: A sourcebook.

Trianto. (2010). Model Pembelajaran Inovatif Berorientasi Konstruktivis. Surabaya: Pustaka Ilmu.

Undang-undang Nomor 24 Tahun 2007 Tentang Penanggulangan Bencana Nasional (Jakarta: Departemen dalam Negeri Jakarta) P2

Yanuarto, T., Pinuji, S., Utomo A C, \& Satrio I T. (2019). Buku Saku Tanggap Tangguh Menghadapi Bencana. Jakarta : Pusat Data Informasi dan Humas BNPB.

\section{Author (s):}

* Siti Nurvitasari

Postgraduate Program of Science Education Study Program

Universitas Negeri Surabaya,

J1. Lidah Wetan, Surabaya 60213, Indonesia

Email: siti.19043@mhs.unesa.ac.id

\section{Madlazim}

Department of Physics, Faculty of Mathematics and Natural Science,

Universitas Negeri Surabaya,

Jl. Ketintang, Surabaya 60231, Indonesia

Email: madlazim@unesa.ac.id

Wasis

Department of Physics, Faculty of Mathematics and Natural Science,

Universitas Negeri Surabaya,

Jl. Ketintang, Surabaya 60231, Indonesia

Email: wasis@unesa.ac.id 